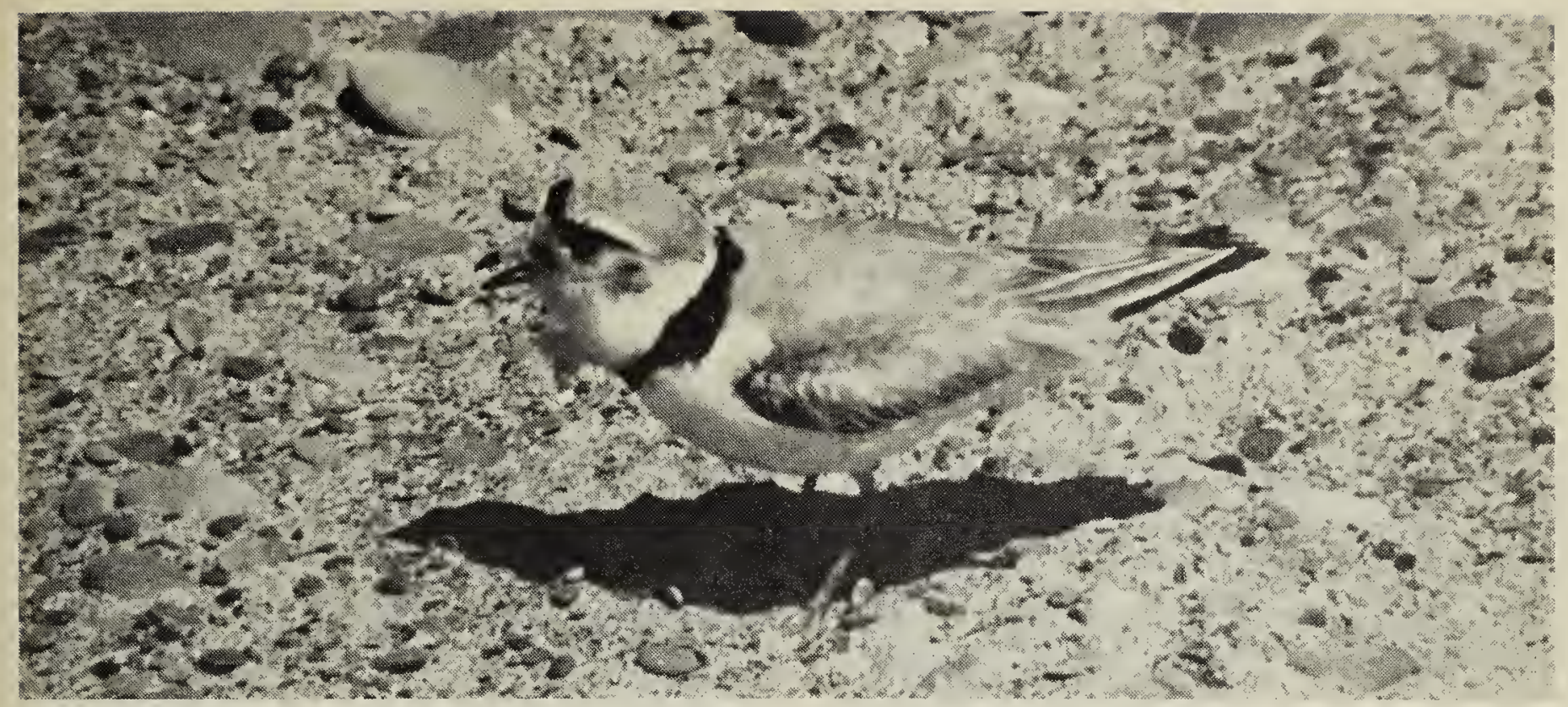

Piping Plover at Long Point.

G. Holroyd

\section{PIPING PLOVER - HOW MANY ARE LEFT?}

No one knows. There may be 1,500 birds on the Atlantic coast but fewer than 100 on the Great Lakes. The prairie populations and coastal wintering areas have never been censused.

Piping Plovers are a shorebird species threatened throughout their North American range. Increased development of their specialized, unvegetated beach habitat may cause more populations to disappear, unnoticed.
In an effort to determine the current status and distribution of Piping Plovers, the World Wildlife Fund (Canada), Delta Waterfowl Research Station and Manitoba Department of Natural Resources are soliciting help in locating birds on breeding, migration or wintering areas. Please support this project by reporting past or present sightings of Piping Plovers (include date, location, number of birds and color bands, if any). Send information to: Susan Haig, Delta Waterfowl Research Station, Portage la Prairie, Manitoba, Canada. R1N $3 A 1$

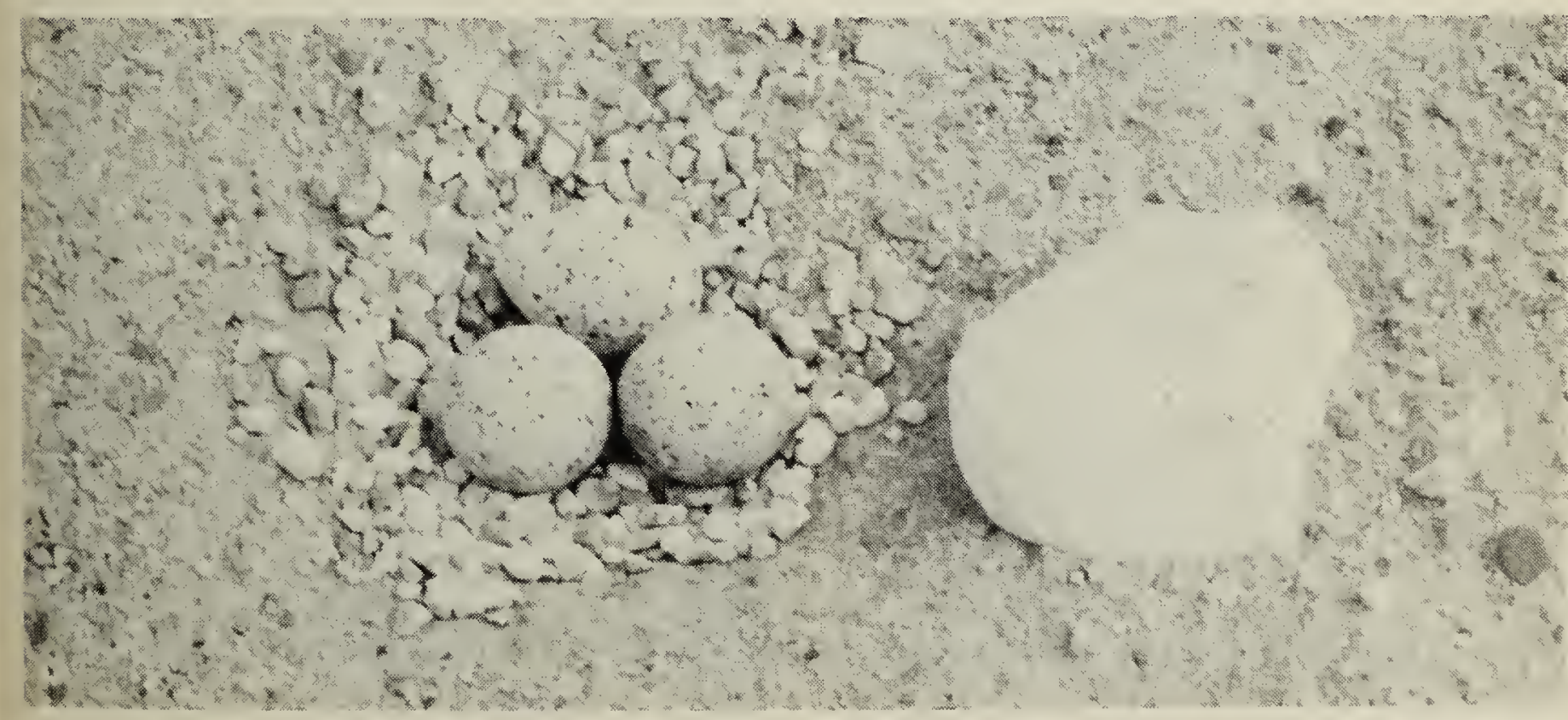

